BOŻYDAR ZIÓŁKOWSKI

\title{
Effectitions as a new instrument in sustainable development policy - the conceptual approach
}

Ph.D. Eng. Bożydar Ziółkowsk Rzeszów University of Technology

\section{Introduction}

The groundbreaking changes in the international development policy emerged at the end of the 20-th century. The growing awareness of the necessity to implement new values in international institutions worldwide was expressed in 1992 during the Rio de Janeiro Earth Summit. The assumptions about the sustainable development concept $t^{1}$ at that time accepted by the majority of the countries were a basis for creating a broad range of instruments for supporting new kind of a policy. The general aim of that sustainable development policy was generational justice which required satisfying in a sustainable way the environmental, social and economic needs. The main reason for those political efforts was undoubtedly the degradation of the natural environment. All those negative outcomes have also been reflected in the social and economic sphere. In order to counteract the observed threads it was necessary to implement solutions that would guarantee environmental stability which is a functional

1 It is also described in this paper as 'ecodevelopment' and 'stable development'.

Effectitions as a new instrument in sustainable development policy - the conceptual approach 
basis in each civilization development. Thus, the time of intensive works on the environment protection technologies has begun.

Currently, many solutions reducing or eliminating environmental impacts are in use. They have been introduced to the economic practice quite successfully. It is worth mentioning such ideas as, e.g. low carbon economy, ecoinnovations, dematerialization, cleaner production, environmental management systems, ecological modernization, or closed-loop economy. The critical literature study reveals that the scientific debate on these issues relates mostly to recommendations on how to diminish negative human environmental pressures. Much less attention in research and development sphere is attributed to technologies which do not have environmental harm. Many management models tend to combine technologies which do not have environmental harm with those which do cause environmental harm. This tendency is not helpful in effective implementation of sustainable development. This is a relevant problem, especially in the management field which requires to improve the existing concepts of socio-economic development. The aim of this paper is to present the effectitions concept designed for implementation of sustainable development rules as well as solid evidence for long-lasting evolution in this area. Effectitions, defined as the solutions which have none negative environmental impact, are incorporating into the researches on effective implementation of sustainable development principles and are a model for planned future policy actions.

Because this study adopted a holistic research perspective, the subject of the presentation were leading trends so far worldwide in sustainable development policies implementation. Its low effectiveness is remarkable above all on the example of lasting several years the global economic crisis, which in the context of effectitions deserves especially in-depth analysis, that will no doubt the subject of many future studies revising, and in this sense opening to existing concepts and theories that determine the development of asymmetry in global reality.

\section{Sustainable development versus ecoinnovations}

\subsection{Sustainable development}

The beginnings of the "sustainable development” trend mark themselves in ancient times. One remarkable case is a historic episode of H. C. von Carlowitz who used this term in the context of forest management practice (see: Ziółkowski 2012, p. 34; Zabłocki 2002, p. 7; Siemens' sights, pp. 18-20). When considering 
the last 50 years it is difficult to precisely answer the question on the outset of interest in sustainable development. We can suppose that the beginnings of the sustainable development concept - viewed as a reference subject for the strategic documents - started when its first definition was formulated. However the effort to set a clear time mark is difficult because of the phraseology and semantic and definition differences which are remarkable among various concepts created for this purpose.

It is true that many terms in this area are considered as synonyms, e.g.: ecodevelopment, continuous/stable development, sustainable development. Moreover, some scientists are expressing different opinions within the same field and they attribute a completely reverse scale of impact to ecodevelopment and sustainable development (see: Kistowski 2003, p. 34, 35). The following presentation of some selected definitions for sustainable development is a good reason to analyze the character of the existing differences more effectively.

Table 1. Some definitions of sustainable development

\begin{tabular}{|c|c|c|}
\hline No & Definition of sustainable development & Source \\
\hline 1 & $\begin{array}{l}\text { Sustainable development is given when the environment of human life } \\
\text { is not affected in significant and nonreversible manner and the rights of } \\
\text { nature, economy and social development are mutually supported as well as } \\
\text { when the sustaining of possibilities in access to resources by present and } \\
\text { future generations are guaranteed. }\end{array}$ & $\begin{array}{l}\text { II Session of the United } \\
\text { Nations Environment } \\
\text { Programme (UNEP) }\end{array}$ \\
\hline 2 & $\begin{array}{l}\text { The World Conservation Strategy attributes the features of sustainable } \\
\text { development to such processes as transformation of biosphere and } \\
\text { utilization of resources (human, economic and resources of biotic and } \\
\text { abiotic environment) for satisfying human needs as well as improving } \\
\text { life quality. These processes embrace also social, ecological and economic } \\
\text { factors as well as the amount of natural resources. In case of choosing one } \\
\text { development direction from many others, the mentioned processes embrace } \\
\text { some benefits and losses from the potential choice in the near or far future. }\end{array}$ & $\begin{array}{l}\text { The World Conservation } \\
\text { Strategy (Światowa } \\
\text { strategia 1985) }\end{array}$ \\
\hline 3 & $\begin{array}{l}\text { Sustainable development is such a development that "seeks to meet the } \\
\text { needs and aspirations of the present generation without compromising the } \\
\text { ability to meet those of the future generations". }\end{array}$ & $\begin{array}{l}\text { Report prepared for the } \\
\text { United Nations in } 1987 \\
\text { "Our Common future" } \\
\text { (United Nations 1987) }\end{array}$ \\
\hline 4 & $\begin{array}{l}\text { Sustainable development is also considered as a group of all activities that } \\
\text { improve human life conditions on the Earth and do not lead to degradation } \\
\text { of natural environment. The environmental issue was affirmed in this case } \\
\text { as a general rule for development. }\end{array}$ & Kozłowski 1985 \\
\hline 5 & $\begin{array}{l}\text { Sustainable development is the process of merging the economic and } \\
\text { ecological effectiveness. }\end{array}$ & Madej 1994, ss. 55-60 \\
\hline
\end{tabular}




\begin{tabular}{|c|c|c|}
\hline 6 & $\begin{array}{l}\text { Sustainable development is economic development which has not significant } \\
\text { and nonreversible pressure on human life environment as well as is } \\
\text { combining rules typical for the nature and economic sphere. }\end{array}$ & $\begin{array}{l}\text { Górka, Poskrobko, } \\
\text { Radecki } 1995\end{array}$ \\
\hline 7 & $\begin{array}{l}\text { Sustainable development is economic development which should be socially } \\
\text { desired, economically justified and ecologically accepted. In such a model of } \\
\text { development all processes inside the social system are harmonized with the } \\
\text { processes in the environmental system and there is a balance between these } \\
\text { two spheres. }\end{array}$ & $\begin{array}{l}\text { Dobrzańska, } \\
\text { Dobrzańska, Kiełczewski } \\
1997\end{array}$ \\
\hline 8 & $\begin{array}{l}\text { Stable development underlines that it does not diminish any element in } \\
\text { the group of social and economic aims related to the process of economic } \\
\text { development. This is also combined with maximizing net benefits resulting } \\
\text { from the economic development and guarantying usefulness and quality } \\
\text { of natural resources in long term. Moreover, the consumption of material } \\
\text { goods and services is limited to the ecologically justified level, especially the } \\
\text { need for conservation of appropriate environmental quality for the future } \\
\text { generations and available for everyone. }\end{array}$ & $\begin{array}{l}\text { Fiedor (red.), Czaja, } \\
\text { Graczyk, Jakubczyk } \\
2002\end{array}$ \\
\hline
\end{tabular}

Source: modified and amended on the basis of: Kistowski 2003, s. 31-33

According to the definition adopted during the second session of the United Nations Environment Programme (UNEP) meeting the sustainable development is given when the environment of human life is not affected in significant and nonreversible manner and the rights of nature, economy and social development are mutually supported as well as when the sustaining of possibilities in access to resources by present and future generations are guaranteed. This is a development which results from human activity realized in harmony with natural environment (see: Kistowski 2003, p. 31).

The World Conservation Strategy attributes the features of sustainable development to such processes as transformation of biosphere and utilization of resources (human, economic and resources of biotic and abiotic environment) for satisfying human needs as well as improving life quality. These processes embrace also social, ecological and economic factors as well as the amount of natural resources. In case of choosing one development direction from many others, the mentioned processes embrace some benefits and losses from the potential choice in the near or far future (see: Kistowski 2003, p. 31, according to: Swiatowa strategia 1985). It is remarkable that both definitions mentioned above underline the three-dimensional character of the discussed phenomenon as they are linked to social, ecological and economic needs.

The next important interpretation of sustainable development was introduced in "Our Common future" report prepared for the United Nations in 1987. 
According to the statement, sustainable development is such a development that "seeks to meet the needs and aspirations of the present generation without compromising the ability to meet those of the future generations" (United Nations 1987). Because of the very general character of this definition it resembles to some extend an organizational mission.

Sustainable development is also considered as a group of all activities that improve human life conditions on the Earth and do not lead to degradation of natural environment (Kistowski 2003, p. 31, according to: Kozłowski 1985). The environmental issue was affirmed in this case as a general rule for development. Another proposal tends to define sustainable development as the process of merging the economic and ecological effectiveness (Kistowski 2003, p. 32, according to: Madej 1994, pp. 55-60).

Many authors view sustainable development in relation to economic development. They assess this model of development as lacking significance and nonreversible pressure on human life environment as well as combination of rules typical for the nature and economic sphere (see: Kistowski 2003, p. 32, according to: Górka, Poskrobko, Radecki 1995).

Other authors claim that sustainable development is economic development which should be socially desired, economically justified and ecologically accepted. In such a model of development all processes inside the social system are harmonized with the processes in the environmental system and there is a balance between these two spheres (compare: Kistowski 2003, p. 32, according to: Dobrzańska, Dobrzańska, Kiełczewski 1997).

Another sustainable development definition presented in the context of stable development underlines that it does not diminish any element in the group of social and economic aims related to the process of economic development. This is also combined with maximizing net benefits resulting from the economic development and guarantying usefulness and quality of natural resources in long term.

Moreover, the consumption of material goods and services is limited to the ecologically justified level, especially the need for conservation of appropriate environmental quality for the future generations and available for everyone (Kistowski 2003, p. 33, according to: Fiedor (red.), Czaja, Graczyk, Jakubczyk 2002).

When analyzing definitions of sustainable development some specific aspects of this concept can be noticed, which however are not always included in each of the analyzed interpretations.

Because some definitions of sustainable development do not always include all 
elements typical for other numerous definitions it is apparent that the proposed concept of effectitions is constructed in another way. This approach does not negate the existing complexity of sustainable development terminology which has been compared by P. Martens to quantum theory. In its own nature the idea of ecodevelopment seems to be simple as such because it should provide for the fundamental needs of humankind without violating the natural system of life on earth (Martens 2006, pp. 36-41, p. 36, according to: National Research Council 1999).

In the context of the presented complexity, a special importance has the 1992 the UNEP's aegis conference. This event was one of a kind in the history of humankind as it trailed the direction for numerous differentiated approaches towards sustainable development. The conference created also a chance to collect firm acceptance from the representatives of the majority world's countries for creation and adaptation of a new model of civilization development. It resulted in new political declarations aimed at supporting that new concept of sustainable development. This was also a moment for creation of new instruments for implementing the created rules. A special importance in this context had the concept of ecoinnovations which will be presented in the next chapter.

\subsection{The nature of ecoinnovations}

Ecoinnovations are a result of evolution within the sustainable development sphere. They are perceived as an instrument for implementation of ecodevelopment rules, although, according to some authors (Machnig 2007) it is even right to compare the potential of ecoinnovations to steam engine and internet revolution in the process of civilization progress.

The analogy of sustainable development and ecoinnovations is remarkable in terms of phraseology and the different interpretations presented in the definitions below. According to C. Ryan, every type of innovation can be called ecoinnovation as long as it guarantees significant improvement in economic and ecological (environmental) outcomes (Ryan 2004, p. 29). Carley and Spapens also consider as ecoinnovations some integrated solutions aimed at diminishing the use of resources and increasing the quality of products and services (Carley, Spapens 2000, p. 157).

It is worth noticing that in the cited definitions the social reference is missing. Beise and Rennings acknowledge the importance of environmental and economic aspects and claim that ecoinnovations are also such solutions which are not determined by environmental harm reduction, but rather by the social 
goals (Beise, Rennings 2003, p. 8, according to: Rennings, Zwick 2002, pp. 319342; Rennings 2000, pp. 319-332; Carrillo-Hermosilla, del Río González, Könnölä 2009, p. 7, according to: Keeble, Lyon, Vassallo, Hedstrom, Sanchez 2005).

Ecoinnovations have a very broad scale of impact. The definitions refer to social, environmental and economic sphere which are the main elements of sustainable development. For this reason other terms are used to describe ecoinnovations, e.g.: innovations of sustainable development, ecological ecoinnovations, environment friendly innovations (Fichter, Noack, Beucker, Bierter, Springer 2006, p. 42; Ziółkowski 2009, p. 14, 15), or environmental/ecological technologies, ecotechnologies, green technologies, etc. Technologies which are commonly considered as ecoinnovations embrace the following:

- reactive solutions, the so called end-of-pipe technologies,

- cleaner production,

- open-loop life cycle technologies, e.g. cradle to grave,

- closed-loop cycle of material and energy, e.g. the concept of cradle to cradle.

The broad impact of ecoinnovations is obvious. However in numerous considerations they are usually defined as technologies that allow for diminishing negative environmental impact. This is a main feature of ecoinnovations and also the leading aim of investments oriented on these solutions. A significantly lower importance (because of not being discussed so far) has the method of diminishing the negative environmental impact. In general, the socio-economic entities define ecoinnovations as all solutions which are leading at least to the minimum extend to the improvement of environmental indicators as compared to other technologies. From the holistic point of view this perspective causes serious problems in effectiveness of sustainable development implementation realized by means of ecoinnovations.

The first problem is a specific economic model which is not based on a single reference point during the assessment process of new technologies. The criteria used for selecting ecoinnovations are adopted very often on the microscale i.e. to ecological innovativeness of solutions introduced on the enterprise level. Criterions for assessment of ecoinnovations on the regional or national scale are also used. However, the inclusion of international trends during the assessment of ecoinnovativeness in many sectors is very rare. This is a reason for implementing ecoinnovations which generate slightly lower pollution than the commonly used innovations, whereas the environmentally harmless technologies are available worldwide.

The second problem resulting, from the commonly accepted perception of ecoinnovations, is technological orientation. It causes the social dimension

Effectitions as a new instrument in sustainable development policy - the conceptual approach 
of ecoinnovations to be neglected during the formulation of development policy. Such an approach is a significant barrier for creating social climate aimed at ecoinnovations.

The third problem related to the general perception of sustainable development innovations is linked with an approach attributing the ecoinnovation features to solutions which cause imbalance in ecodevelopment systems. Despite detailed analyses of possible harm, it is enough to mention some examples of threats such as: some genetic modifications, especially of food products or environmental risk of nuclear energy.

All the factors mentioned above institute a threat for dissemination of sustainable development and need improvement activities. This is a reason for adoption of the new ecoinnovations approach and its implementing as a new concept in the area of sustainable development. The presented concept is an example of evolution among ecoinnovation and is presented in the next chapter.

\section{Ecoinnovations versus effectitions}

The analysis of definitions presented above allows to formulate practical conclusions with serious implications for research and civilization development. Ecoinnovations are defined twofold. According to majority of authors, ecoinnovations are new products, techniques, practices, processes and systems which allow to eliminate or reduce harmful impact on environment (Kemp, Andersen 2004, p. 70). On the other hand, other definitions establish ecoinnovations as solutions aimed at real improvement in environmental status (Ziółkowski 2012, p. 109; PSDB 2010, according to: Urbaniec (w:) SidorczukPietraszko 2009, p. 59, according to: Macharzina 1999, p. 553). These different interpretations are representing two distinctive viewpoints. In order to promote each of these two approaches it is often necessary to choose specific financial and legal instruments. This can determine also a method of designing the socioeconomic policy and business models. The unequivocal differentiation between these two aspects of ecoinnovations i.e. reduction and complete elimination of environmental harm plays also a key role in the time of socio-economic crisis. Increasing prices of natural resources are a solid evidence that the scenarios of fast resources depletion have started. Similarly more restrict fiscal policy for the environment protection is a signal for acute problems of biosphere degradation. However, all investments aimed at supporting ecoinnovations that generate pollution or diminish natural resources lead to strengthening dangerous threats. Such situations can be assessed as a sign of the deficit in constructive solutions 
from the management sphere. The implementation of ecoinnovations does not always guarantee instant improvement in environment and is not an equivalent to the lack of emissions because ecoinnovations lead often just to reduction in environmental harm like e.g. cleaner technologies. Thus the effectiveness in implantation of ecodevelopment rules, which are a guaranty for sustainable satisfaction of needs in social, environmental and economic sphere, is not fully grounded.

To counteract the perceived threats as well as to accelerate the process of disseminating the sustainable development rules it is necessary to support just these ecoinnovations that do not have any environmental harm. They are called effectitions according to a new concept published in $2012^{2}$. These solutions are instruments for implementation of ecodevelopment policy and a result of evolution among the ecoinnovation terminology. Effectitions are also described as effective ecoinnovations in the sense of praxeological dimension of effectiveness defined according to the zero-one principle. Effectitions are also an example of the final effect in realization of industrial ecology purposes and especially the ecodesign idea "from cradle to cradle". The definition mentioned above can trigger some questions about the necessity for creation of new terms and expressions to describe innovations which seemed to be very well categorized.

When assessing the global market turbulence and very short product life cycle it would be very risky to assume that the innovation theory was already so well developed that it should not evaluate fast and multilaterally in the future. The dynamics of the present socio-economic life causes many ununderstandable changes in every day life and determines the methods for research and development. Therefore, many new solutions which are already used in some disciplines of theory and economic practice have not been incorporated into theory of innovations. The difficulty in assigning a proper name or category and sometimes even identification of tendencies, trends or technologies is typical for every research discipline and is one of the basic challenges. The concept of effectitions should be considered as an effect of meeting these challenges and a proof of the scientific diagnosis.

When explaining once again the reasons for creating this new concept in the context of the presented specificity and differentiation of ecoinnovations, it is

2 This issue along with research results was presented by: B. Ziółkowski, Ewolucyjne podejście do ekoinnowacji i zrównoważonego rozwoju - ujęcie systemowe, Poligrafia Wyższego Seminarium Duchownego w Rzeszowie, Rzeszów 2012. 
justified to ask a question about the necessity of implementing the "effectitions" phrase and concept. Is it necessary to formulate new terms to underline some specific feature like in the case of effectitions? It is obvious that some definitions of ecoinnovations comprise also such technologies which do not generate any environmental harm. The formulated questions are not just examples for academic discourse. Similarly like ecoinnovations introducing effectitions has a practical importance.

Apart from the context of the discussed considerations, the mentioned questions are typical for discussion on e.g. the necessity of differentiation between the ecological food and fast-food or between the renewable and conventional energy technologies. There is no doubt that the promotion of one of these two categories determines the direction in the evolution of sustainable development.

Another justification for the adoption of the effectitions concept is the lack of similar constructs, especially in the innovation theory. This can be proved with the example of effectitions and clean technologies which both are similar, but just seemingly. The evidence for that is e.g. the strategic report on clean coal technologies which stresses the role of clean technologies in reduction of SOx and NOx emissions released during the combustion which causes improvement in effectiveness of energy generation (SBI 2012).

Hammar and Lofgren presented attributes of clean technologies in the context of pollution preventive methods as compared to "end-of-pipe technologies". They distinguished between clean technologies and "end-of-pipe technologies" which are focused on eliminating and preventing dissemination of pollution. The aims of clean technologies implementation are as follows (Hammar, Lofgren 2010, pp. 3644-3651):

- reduction in pollution emissions generated in the production process,

- use of resources with lower impact on environment as compared with other resources,

- use of infrastructure and processes with lower impact on environment as compared with other processes.

The application of the economic criterion also unveils remarkable distinctions between the presented technologies. Clean technologies give a guaranty for higher resource efficiency and increase in production without increasing pollution. The application of the "end-of-pipe technologies" provides solutions just for treatment of the already generated pollution. This approach does not allows either to increase resource efficiency or influence the production process (Hammar, Lofgren 2010, pp. 3644-3651). The presented examples provide an evidence for the lack of congruence between clean technologies and effectitions.

It would be very useful to make a broad research on effectitions especially 
in the context of their systemic implementation, i.e. model of effectitions. In the framework of international initiatives aimed at creation of innovation and research policy, the decisions on sustainable development should also include the creation of independent markets for ecoinnovations and effectitions. The issues considered in this paper have a special importance in the era of the development crisis. Their real potential for improvements of the socio-economic situation is very impressive. The availability of solutions from this sphere is however still a technological challenge in many areas of human activities. For this reason it is necessary to improve multilaterally the innovation policy in all countries, especially in the context of intensifying the research and development activities.

\section{Conclusions}

When adopting the viewpoint of a critical commentator it should be stressed the concepts which are the effect of scientific development and progress are often resulting from evolution of the already known solutions.

Depending on the nature of changes, there is always a remarkable similarity between new concepts and the earlier scientific legacy. This is a natural and evolutionary process of improving every human idea and this is also true with the effectitions presented in this paper.

When accepting the viewpoint of an objective observer, it should be noticed that the innovation theory does not possess so far any distinct category to describe just these solutions that do not have negative environmental impact. Despite the tacit idea on this matter in scientific circles it has not been expressed by words or defined like effectitions or any other concept in a distinct and autonomic way.

A similar case refers to the commonly used definitions of ecoinnovations that were very often interpreted vaguely. Among many reasons for that situation, the observed changes were mainly determined by scientists trying to improve the original definition by $\mathrm{C}$. Fussler who included in ecoinnovations not only those solutions which eliminated but also those that reduced environmental impacts. Similarly, the efforts oriented on the creation of "cleaner technologies" have been adopted by the market as a synonym for "clean technologies". The presented initiatives for the creation of a new market niche were not successive because they did not trigger a global acceptance for such a sublimated form of ecoinnovations. Therefore, the international policy is not promoting, either explicitly or in a systemic manner, the trajectories supporting the development of just those technologies that have "zero" negative environmental impact. The need of creating two distinctive technology markets (i.e. the first one which is completely harmless for the environment and the second one with partial negative 
impact on environment) have not been discussed in the literature so far. On the contrary, the currently promoted ecoinnovations policy does not underline the existing specificity conceptualized and defined just by the concept of effectitions. For the civilization progress, the implementation of sustainable development undoubtedly requires adopting the effectition perspective altogether with the concept of the systemic development of effectitions. Finally, the key question is: When should the new instruments - created for implementing sustainable development and guarantying the lack of environmental harm - be incorporated in their original, unchanged form to strategic and legal documents and when should they be reflected in the international socio-economic life? The answer will be delivered by the future global environmental events.

\section{Summary}

Effectitions as a new instrument in sustainable development policy - the conceptual approach

Effective dissemination of sustainable development is possible when the instruments for its implementation are continuously improved. The concept of effectitions is an example of such an approach. It extracts from the group of innovations for sustainable development, such technologies which have no negative environmental impacts. The presented paper presents the nature of effectitions in the context of eco-innovations and sustainable development policy.

Keywords: effectitions, eco-innovations, sustainable development, environment protection

\section{Streszczenie}

Słowa

Efektycje jako nowy instrument $\mathrm{w}$ polityce zrównoważonego rozwoju - ujęcie koncepcyjne

Skuteczne upowszechnianie ekorozwoju możliwe jest dzięki doskonaleniu instrumentów jego wdrażania. Koncepcja efektycji stanowi przejaw takiego podejścia. Wyodrębnia ona z grupy innowacji zrównoważonego rozwoju jedynie te technologie, które nie wykazują jakiegokolwiek negatywnego wpływu na środowiskowo. Niniejszy artykuł omawia istotę efektycji w kontekście teorii ekoinnowacji i polityki zrównoważonego rozwoju.

kluczowe: efektycje, ekoinnowacje, zrównoważony rozwój, ochrona środowiska 


\section{References}

1. Beise M., Rennings K. (2003), Lead Markets of Environmental Innovations: A Framework for Innovation and Environmental Economics, Discussion Paper No. 03-01, ZEW, Mannheim.

2. Carley M., Spapens P. (2000), Dzielenie się światem. Zrównoważony sposób życia i globalnie sprawiedliwy dostęp do zasobów naturalnych w XXI wieku, Wyd. Instytut na rzecz Ekorozwoju, Białystok - Warszawa.

3. Carrillo-Hermosilla J., Del Río González P., Könnölä T. (2009), Ecoinnovation, when sustainability and competitiveness shake hands, Palgrave, Macmillan, CPI Antony Rowe, Chippenham and Eastbourne.

4. Dobrzańska G., Dobrzańska B.M., Kiełczewski D. (1997), Ochrona środowiska przyrodniczego, Wyd. Ekonomia i Środowisko, Białystok.

5. Fichter K., Noack T., Beucker S., Bierter W., Springer S. (2006), Nachhaltigkeitskonzepte fuer Innovationsprozesse, Fraunhofer IRB Verlag, Stuttgart.

6. Fiedor B. (red.), Czaja S., Graczyk A., Jakubczyk Z. (2002), Podstawy ekonomii środowiska i zasobów naturalnych, Wydawnictwo C.H. BECK, Warszawa.

7. Górka K., Poskrobko B., Radecki W. (1995), Ochrona środowiska. Problemy spoteczne, ekonomiczne i prawne, Polskie Wydawnictwo Ekonomiczne, Warszawa.

8. Hammar H., Lofgren A. (2010), Explaining adoption of end of pipe solutions and clean technologies-Determinants of firms' investments for reducing emissions to air in four sectors in Sweden, "Energy Policy" 38, 3644-3651.

9. Keeble J., Lyon D., Vassallo D., Hedstrom G., Sanchez H. (2005), How Leading Companies are Using Sustainability-Driven Innovation to Win Tomorrow's Customers, A. D. Little.

10. Kemp R., Andersen M.M., Butter M. (2004), Background report about strategies for eco-innovation. Report for VROM, zaaknummer 5060.04.0041, Final version, 22 May.

11. Kistowski M. (2003), Regionalny model zrównoważonego rozwoju i ochrony środowiska Polski a strategie rozwoju województw, Uniwersytet Gdański, Bogucki Wydawnictwo Naukowe, Gdańsk-Poznań.

12. Kozłowski S. (1985), Ekorozwój. Koncepcje ekorozwoju, „Człowiek i Światopogląd" 5/232.

13. Macharzina K. (1999), Unternehmensführung, Gabler, Wiesbaden.

14. Machnig M. (2007), Ökologische Industriepolitik - Strategie für Umwelt und Wirtschaft, Böll. Thema, nr 1.

15. Madej T. (1994), Rozwój regionalny a środowisko przyrodnicze, „Ekonomia i Środowisko", nr 1 (4), p. 55-60.

16. Martens P. (2006), Sustainability: science or fiction? „Sustainability: Science, Practice \& Policy" 2(1).

17. National Research Council (NRC) (1999), Our Common Journey: A Transition Toward Sustainability, National Academy Press, Washington DC.

Effectitions as a new instrument in sustainable development policy - the conceptual approach 
18. PSDB, RAPORT Ochrona środowiska i ekoinnowacje (2010), http://www.efs. gov.pl/AnalizyRaportyPodsumowania/baza_projektow_badawczych_ efs/Documents/RAPORT_Ochrona_srodowiska_i_ekoinnowacje.pdf (z dnia: 03.03.2011).

19. Rennings K. (2000), Redefining innovation - eco-innovation research and the contribution from ecological economics, "Ecological Economics” 32, p. 319-332.

20. Rennings K., Zwick T. (2002), The Employment Impact of Cleaner Production on the Firm Level - Empirical from a Survey in Five European Countries, "International Journal of Innovation Management”, Special. The Management of Innovation for Environmental Sustainability 6(3), p. 319-342.

21. Ryan C. (2004), Digital Eco-Sense: Sustainability and ICT - A New Terrain for Innovation, lab.3000, Carlton Victoria.

22. SBI (2012), Clean Coal Technologies Markets and Trends Worldwide, 2nd Edition, Market Publishers Ltd, Leaflet, http://pdf.marketpublishers. com/sbi/clean_coal_technologies_markets_n_trends_worldwide_2nd_ edition.pdf (accessed on: 13.06.2012).

23. Siemens' sights on sustainability. But employees think there's a long way to go (2004), „Strategic Direction” nr 20 (10), p. 18-20.

24. Światowa strategia ochrony przyrody. Ochrona żywych zasobów dla trwałego rozwoju (1985), IUCN, UNEP, WWF, Liga Ochrony Przyrody, Warszawa.

25. United Nations (1987), General Assembly, 4 August 1987, English. Forty-second session. Item 83 (e) of the provisional agenda, A/42/427. Development and international economic co-operation: environment. Report of the World Commission on Environment and Development. Annex: Our Common Future.

26. Urbaniec M. (2009), Wpływy innowacji ekologicznych na rozwój zrównoważony, (w:) Sidorczuk-Pietraszko E., Funkcjonowanie przedsiębiorstw w warunkach zrównoważonego rozwoju i gospodarki opartej na wiedzy, Wyd. WSE, Białystok.

27. Zabłocki G. (2002), Rozwój zrównoważony: idee, efekty, kontrowersje (perspektywa socjologiczna), Wyd. Uniwersytetu Mikołaja Kopernika, Torun.

28. Ziółkowski B. (2012), Ewolucyjne podejście do ekoinnowacji i zrównoważonego rozwoju - ujęcie systemowe, Poligrafia Wyższego Seminarium Duchownego w Rzeszowie, Rzeszów.

29. Ziółkowski B. (2009), Foresight w strategicznym rozwoju ekoinnowacji regionu - pierwsze doświadczenia Polski, Wydawnictwo i Drukarnia Diecezji Rzeszowskiej, Rzeszów. 